\title{
Lakásrezsim és a devizahitel-válság: intézményi és egyéni stratégiák'
}

\author{
Csizmady Adrienne - Hegedüs József - Vonnák Diána
}

https://doi.org/10.51624/SzocSzemle.2019.1.1

Beérkezés: 2018. 10. 04.

Átdolgozott változat beérkezése: 2019. 03. 27.

Elfogadás: 2019. 04. 10.

\begin{abstract}
Összefoglaló : A tanulmány a devizahitel-válság kialakulását és következményeit elemzi a lakásrendszer kontextusában. A lakásprivatizációt előtérbe helyező, az államilag támogatott lakásfinanszírozást felszámoló lakáspolitika 1990 után egy torz lakásrezsimhez vezetett, amely a piaci hitelekkel finanszírozott magántulajdon kiszélesítésében látta a megoldást az alacsonyabb jövedelmű rétegek lakáshelyzetének rendezésére is. Ez a 2000-es évek elején kezdődő hitelpiaci expanzióval, kamat- és egyéb támogatásokkal indult. 2004 után leginkább alacsony kamatozású, kockázatos, devizaalapú hiteltermékek ösztönözték a növekedést. A 2000-es évek elején meginduló trendek közepette ez reális stratégiának tűnt: az intézményi és a lakossági szereplők számára tarthatónak látszott a jelzálog-hitelezésre épülő megoldás. A 2008-as válság alapvetően megváltoztatta a helyzetet: a devizahitelek veszteségessé váltak, így megindult a veszteség költségeinek elosztására irányuló politikai-társadalmi vita, amelyben a szereplők ellenérdekeltek voltak. $\mathrm{Az}$ egységes értelmezést inkompatibilis értelmezések és a hozzájuk kapcsolt megoldási javaslatok váltották fel. A tanulmányban amellett érvelünk, hogy a szereplők alkalmazkodási stratégiái és viselkedése újra megerősítették a lakásrezsim torz elemeit. 2015 után a gazdaság (EU-támogatásokból finanszírozott) stabilizációjára épülő lakáspolitika ismét a piaci finanszírozású magántulajdonra épít, elfeledkezve a megelőző másfél évtized kudarcáról.
\end{abstract}

Kulcsszavak: lakásrezsim, lakásstratégia, devizahitelezés, háztartások alkalmazkodása

\section{Bevezetés}

A tanulmány egy újszerú megközelítésre építve (Hegedüs 2018) amellett érvel, hogy a posztszocialista lakásrendszerben a szociálisbérlakás-szektor rezidualizálódik, mivel a magasabb státuszú csoportok (és a jobb minőségű lakásállomány) a privatizáció következtében kikerülnek a szektorból. A magánbérlakás-szektort leginkább egy szűk réteghez sorolható

1 A tanulmány a Lakáshitellel eladósodott családok helyzetének vizsgálata címú (NKFIH - K109333 számú), az MTA TK és a Városkutatás Kft. együttműködésében zajló kutatás keretében készült. A szerzők köszönettel tartoznak Király Júliának és Várhegyi Évának a tanulmányhoz fúzött javaslataikért, valamint a Szociológia Szemle anonim bírálóinak. 
háztartások (egyetemisták és a családalapítás előtt álló egyedülállók) választják, sokszor az alternatív lakásmegoldásokból kiszorulók kényszermegoldásává válik.

A lakásfinanszírozási rendszer 1990 utáni összeomlása a posztszocialista országokban torz lakásrezsim kialakulását eredményezte, ahol a magántulajon - gyakran kvázi piaci környezetben - domináns szerepet kapott. Az EU-hoz csatlakozó posztszocialista országok lakáspolitikai dokumentumaiban a gazdaság stabilizálódását követően megfogalmazódott e modell korrekciós igénye. Ez egyrészt a piaci lakásfinanszírozási rendszer kiépítését, másrészt a szociális lakásszektor bővítésének tervét foglalta magába. A gazdasági és politikai érdekek azonban inkább a lakásfinanszírozási rendszer kiépítéséhez füződtek, a szociális lakásprogramok rendre háttérbe szorultak.

Magyarország is beleillett ebbe a trendbe: a magánlakás-piaci szegmens 1990 után folyamatosan erősödött. A 2000-es évek hitelpiaci bővülése mögött az a várakozás húzódott meg, hogy a hitelezés az alsó középosztály gazdasági integrációját fogja eredményezni. Ezt erősítette az is, hogy a hitelezés felfelé ívelő szakaszában egységes felfogás alakult ki a lakosság, a politikai és pénzügyi szereplők között, amely szerint a magántulajdon széles rétegek számára jelent megfizethető lakhatási alternatívát. A politikai támogatást élvező hitelezés következtében a jelzáloghitel GDP-n belüli aránya gyorsan emelkedett 2000 és 2004 között. 2004-től a támogatott hiteleket devizahitelek váltották; ezek terjedése Magyarországon majdnem olyan gyors volt, mint a balti országokban (Barel et al. 2009). Ráadásul a bankok közötti verseny révén, és a felügyelet lazasága miatt (Király-Nagy 2008) a jelzáloghitelekhez az alacsonyabb jövedelmú, bizonytalan munkaerőpiaci pozícióval rendelkező háztartások is egyre inkább hozzáfértek. A 2008-as válság miatt ez az egységes értelmezés azonban felbomlott, megkérdőjeleződött.

A tanulmány fő kérdése, hogy milyen lakáspolitika vezetett a válsághoz, milyen stratégiát követett a kormányzat, hogyan reagáltak a kormányzati programokra a különböző lakossági csoportok, és ennek következtében milyen változások következtek be a lakásrendszerben.

A tanulmány első részében a lakásrendszer egy új értelmezési keretét állítjuk fel, amelynek fontos eleme a struktúra és az egyéni/intézményi stratégiák közötti interakció(k). A második részben áttekintjük a 2000 utáni lakáshitel-expanzió egyes időszakait és a lakáshitelt felvevő háztartások tipikus motivációit. A harmadik részben, kiindulva a válság okozta konfliktusok alternatív értelmezéseiből, leírjuk a főbb „adósmentő" programokat és a rájuk adott tipikus válaszokat. Az összefoglalásban arra is kitérünk, hogy a devizahitel-válság milyen irányú változásokat hozott a magyar lakásrezsimben.

A tanulmányhoz dokumentumokat, szakértői interjúkat és a hitelt felvevő háztar-

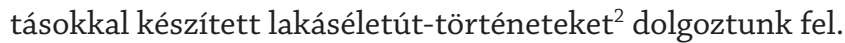

2 A kutatás keretében 30 strukturált mélyinterjú készült devizahitelesekkel, ezt 9 további esettel egészítettük ki más kutatásokban, sajtóban megjelent riportok, internetes fórumokon elmesélt történetek alapján, aminek a célja egy olyan „esetbank" felállitása, amely betekintést ad a lakossági válaszok természetébe. Az így létrehozott 39 esetre épül a kvalitatív kutatás, amely az elméleti megállapításokhoz keresett illusztrativ eseteket (lásd.: 3. táblázat). 


\section{A lakásrezsim értelmezése - struktúra és a szereplők interakciói}

\section{A lakásrezsim átalakulása a rendszerváltás után}

A lakásrezsim értelmezéséhez fontos megkülönböztetni a lakásrendszert és a lakásrezsimet. A lakásrendszeren intézmények, szereplők, szabályok összességét értjük, a lakásrezsimet pedig ennek egy értelmezési kereteként definiáljuk. Ahhoz tehát, hogy a lakásrezsim átalakulását vizsgálni tudjuk, először a lakásrendszert kell áttekintenünk.

A lakásrendszerek értelmezésének két főbb irányzatát különböztethetjük meg. Az 1980-as években a lakásszektor beágyazottságát hangsúlyozó (housing provision) megközelítés uralkodott (Ball-Harloe 1992), amelyben a lakásformák, a strukturalista elmélet logikájának megfelelően, társadalmilag és politikailag meghatározott elosztási-termelési módozatokat reprezentáltak. Ezt a felfogást váltotta fel Kemeny (1995) elmélete, amely a bérlakás-szektor szerkezete alapján állított fel két alapmodellt (az univerzális és reziduális modellt), melyeket azután finomított. A tanulmányban e két megközelítés kombinációjaként definiált speciális részpiac-mátrix segítségével írjuk le a lakásrendszert, ahol a mátrix celláit (lakhatási formák) a lakásszektor domináns integrációs mechanizmusaiként és a tipikus tulajdoni/jogi formák kombinációjaként határozzuk meg (Hegedüs 2018). ${ }^{3}$

Az 1989-90-es politikai-gazdasági fordulat a szocialista országok lakásrendszerének lényeges átalakulását hozta. A rendszerváltás utáni évtizedben két alapvető változás történt. Egyrészt a lakásprivatizáció következtében az állami tulajdonú lakásállomány 21\%-ról 3\%-ra csökkent, állami tulajdonban pedig csak a relatíve rosszabb minőségű lakásállomány maradt. Másrészt a lakáshitelezés állami pénzintézeteken keresztüli finanszírozása megszűnt. Az ezek helyett belépő piaci pénzintézetek csak a 2000-es évek elejétől kezdtek lakásvásárlásokat és -építéseket finanszírozni, amikor az infláció kezelhető nagyságú lett. A részpiac-mátrix, összehasonlítva a nyugat-európai modell stilizált verziójával (1. és 2. ábra), jelzi a rendszerváltás utáni lakásmodell főbb gyenge pontjait. Ezek közül talán a legfontosabb a szociális szektor hiánya: ez olyan államilag integrált, szabályozott lakhatási formákat jelentene, amelyek az alacsony jövedelmű társadalmi csoportoknak is biztosítják a megfizethető, alapvető elvárásoknak eleget tevő lakhatást. Másrészt hiányzik egy olyan piaci lakásfinanszírozás, amely számottevő állami segítség nélkül is megfizethető lakásmegoldásokat biztosít a társadalom középosztálya számára. Harmadrészt a magánbérlakás-szektor gyengesége látszik, amely mögött jogi szabályozatlanság és a szektor növekedését gátló kockázatok vannak.

A lakásrezsimet a lakásrendszert leíró részpiac-mátrixhoz kapcsolódó jogszabályok, fiskális (adózási és egyéb támogatási) elemek, illetve az ezekhez kapcsolódó politikai-ideológiai programok együtt határozzák meg. A lakásrendszert olyan intéz-

3 Ezzel párhuzamosan jelentős maradt az institucionalista megközelítés is (Matznetter 2002; Matznetter-Mundt 2012; Malpass 2008; Lunquist 1990; Fitzpatrick-Stephens 2014). 
ményi térként definiálhatjuk tehát, amelyben a részpiac-mátrix által pozicionált lakhatási formákhoz intézményi és egyéni (háztartási) érdekek kapcsolódnak. ${ }^{4}$

A stilizált nyugat-európai részpiac-mátrix (1. ábra) jellemzője, hogy az erős piaci tulajdonosi szektor mellett számottevő szociális és piaci bérlakás-állomány is létezik. A nyugat-európai lakásrendszerek azonban országonként különböznek; számos kísérlet történt e különbségek konceptualizálására. Ezek közül az utóbbi két évtizedben a Kemeny-féle megközelítés vált uralkodóvá, amely integrált és reziduális (bérlakás) modelleket különböztet meg (Kemeny 1995; Kemeny et al. 2005) aszerint, hogy a szociális és piaci bérlakás-szektor milyen kapcsolatban áll egymással. Haffner és munkatársai (Haffner et al. 2009) a különböző bérlakás-rendszereket abból a szempontból vizsgálták, hogy az egyes konstrukciók között mekkora a „távolság” jogi, pénzügyi, elosztási stb. szempontból. Ez a logika jól alkalmazható az általunk felállított részpiacmátrixra is, ahol a különböző tipikus lakhatási formákat reprezentáló cellák közötti „távolság” elemzése lehetőséget ad a lakásrendszerek pontosabb összehasonlítására.

A lakásrendszer változásának dinamikus elemeit a lakásrendszeren belüli érdekek és érdekkonfliktusok jelentik. Ezek a folyamatok kényszerítenek ki jogi változásokat, fiskális intézkedések korrekcióját, és ösztönözik a lakásrendszerre vonatkozó politikai elképzelések módosítását is. A posztszocialista országok gazdaságának stabilizációja után a lakásszektorért felelős politikusok felismerték a lakásrezsim fent említett kritikus pontjait, és a lakáspolitikában helyet kapott a szociális szektor növelésének programja, a magánbérlakás-szektor nagyobb súlyát megteremtő intézkedések és a piaci lakásfinanszírozás megindítása is (lásd: 2. ábra).

4 A lakásrendszer az intézmények, szereplők, szabályok összessége, a lakásrezsim pedig a lakásrendszer egyik lehetséges értelmezési kerete, elmélete. 
1. ábra: A nyugat-európai lakásmodellhez tartozó stilizált részpiac-mátrix

Tulajdoni -jogi státusz

\begin{tabular}{|c|c|c|c|}
\hline & $\begin{array}{l}\text { Közösségi } \\
\text { bérlakás }\end{array}$ & $\begin{array}{l}\text { Magánbér- } \\
\text { lakás }\end{array}$ & $\begin{array}{l}\text { Tulajdonos } \\
\text { által lakott }\end{array}$ \\
\hline $\begin{array}{l}\text { Állam/ } \\
\text { közösségi }\end{array}$ & & & 0 \\
\hline $\begin{array}{c}\text { Piaci } \\
\text { integráció }\end{array}$ & & & \\
\hline $\begin{array}{l}\text { Reciprokatív } \\
\text { (család, } \\
\text { rokonság, } \\
\text { barát) }\end{array}$ & & & \\
\hline
\end{tabular}

2.ábra: A posztszocialista modell (és a 2000 utáni lakáspolitika szándékolt elmozdulási irányai)

Tulajdoni -jogi státusz

\begin{tabular}{|c|c|c|c|}
\hline & $\begin{array}{l}\text { Közösségi } \\
\text { bérlakás }\end{array}$ & $\begin{array}{l}\text { Magánbér- } \\
\text { lakás }\end{array}$ & $\begin{array}{l}\text { Tulajdonos } \\
\text { által lakott }\end{array}$ \\
\hline $\begin{array}{c}\text { Állam/ } \\
\text { közösségi }\end{array}$ & & & 0 \\
\hline $\begin{array}{c}\text { Piaci } \\
\text { integráció }\end{array}$ & & & \\
\hline $\begin{array}{l}\text { Reciprokatív } \\
\text { (család, } \\
\text { rokonság, } \\
\text { barát) }\end{array}$ & & & \\
\hline
\end{tabular}


Ezek a programok a posztszocialista országokban eltérő támogatást kaptak. Általában jellemző, hogy a szociálisbérlakás-programok nem kapták meg a szükséges politikai és költségvetési támogatást, a magánbérlakás-szektor fejlődése lassú volt, a szektor kockázatai miatt elsősorban az egyéni tulajdonosok (lényegében a felső középosztály) portfóliódöntésétől függött, szabályozása pedig nem volt átfogó és elégséges. A lakásfinanszírozási rendszer szerepe viszont egyértelműen nőtt mindenhol, bár az intézményi megoldások és a jelzáloghitelezés volumene országonként eltérő volt (Hegedüs-Struyk 2005).

\section{Háztartási és intézményi stratégiák}

A háztartások és intézmények lakáspiaci viselkedése és interakciói a lakásrezsim fontos, dinamikus elemei. A lakásrezsimek akkor változnak, amikor a háztartások és az intézmények viselkedése - reagálva a gazdasági, fiskális és politikai környezetre - megváltozik, azaz a részpiac-mátrix szerkezete átalakul, és az egyes cellák lakhatási megoldásainak múködési mechanizmusai módosulnak. Ezért fontos kérdés, hogy milyen tényezők befolyásolják ezen szereplők lakáspiaci döntéseit.

A háztartások lakáspiaci stratégiáját alapvetően befolyásolja a társadalmi-gazdasági (osztály-) helyzetük, de a strukturális pozíció csupán döntési valószínűségeket jelent: lakáspiaci döntéseikben a háztartások szélesebb vagy szúkebb döntési szabadsággal rendelkeznek. A lakáséletút-történetek azt is bizonyítják, hogy minden esetben beszélhetünk eltérő alternatívákról; motivációk, döntéshozatali mechanizmusok sokféleségét figyelhetjük meg (Lin 2012). A háztartások döntéseinek számos eleme nem írható le a racionális döntéselméletek segítségével. A behaviorista közgazdaságtan reálisabb megközelítést nyújt, melyben a viselkedési minták követése, a korlátozott racionalitás, a járadékmaximalizálás, az erkölcsi kockázat elfogadott elemzési kategóriák.

A háztartások viselkedésének elemzése során a lakásstratégia mellett nem tekinthetünk el a háztartások egyéb stratégiáitól sem: a lakásstratégia csak a munkaerôpiaci, fogyasztási és nyugdíjstratégiáival együtt értelmezhető, azokba van beágyazva. Krízishelyzetbe kerülhetnek az ezek bármelyikével kapcsolatos hibás döntés vagy előre nem látható kedvezőtlen esemény miatt (például a munkahely elvesztése, irracionális ingatlanberuházás, betegség, válás, baleset stb.). Bármelyik területen jelentkező krízis kihathat a többi területre is.

A háztartási stratégiák az intézményi és politikai környezettel kölcsönhatásban jönnek létre, a közpolitikai döntések, programok, intézményes szolgáltatások által meghatározott lehetőségek figyelembevételével. Ez a keret azonban nem statikus, hanem egyszerre aktív és reaktív, tehát - hasonlóan a háztartások lakáspiaci döntéseihez - érdemes hosszabb időkeretben megnézni a változásait. Például válságkezelési helyzetekben a jóléti rendszer keretein belül új programok indulhatnak, amelyek átalakítják a háztartás lehetőségeinek térképét.

A tágabb család (háztartás) szerepe jelentős a fiatalok lakáshoz jutásában, különösen olyan lakásrezsimekben, ahol a hitelhez való hozzájutás korlátozott. A rokoni és baráti kapcsolatháló kiterjedtsége, anyagi teherbíró képessége meghatározó a hitelpi- 
acra való belépésben (a hitelfelvételben). Ugyanakkor ez a segítség nem teljesen kiszámítható és stabil, gyakran a családon belüli érdekellentétek miatt nem lehet például erre építeni. Ilyen szempontból az első lakáshoz jutó háztartások esetében előfordulhat, hogy a családi segítségben rejlő kockázat nagyobb, mint a bérlésben.

A lakáspiaci intézmények és szereplők (vállalkozók, ingatlanközvetítők, jogászok, bankok, kormányzati szervezetek stb.) viselkedését - hasonlóan a háztartásokéhoz - a jogi keretek, a pénzügyi érdekeltségek és az uralkodó lakáspolitikai koncepciók befolyásolják. Az intézményeknek van egy „küldetésük”, feladatuk, ugyanakkor fennmaradásuk feltétele a politikai és pénzügyi megfelelés; ezek a körülmények könnyen ellentmondásba kerülhetnek egymással. Például az önkormányzatok feladata, hogy a szociális bérlakásokkal az alacsony jövedelmú családok lakáshatását segítse, de az önkormányzatok - mind a pénzügyi, mind a politikai érdekeltségük (újraválasztás) miatt - tipikusan arra törekszenek, hogy megszabaduljanak a „problémás”, szegény bérlőiktől. De a nonprofit szociális elkötelezettségű szervezeteknek is lehetnek a fennmaradásukkal kapcsolatos olyan pénzügyi érdekeik, amelyek átmenetileg vagy részben ellentmondhatnak a küldetésüknek. E szabálytalanságok megismerése hozzájárul a lakásrendszer múködésének megértéséhez.

A háztartások lakáspiaci döntései és az intézmények stratégiái sok szempontból bizonytalan környezetben valósulnak meg. Az urbanizáció és a globális piacgazdaság kiépülésével a gazdasági fejlődés elkerülhetetlen velejárói a gazdasági, természeti stb. krízishelyzetek. A modern társadalmak kockázati társadalmak (Beck 1992; Giddens 1999). A háztartások számára a kockázati társadalmak olyan helyzeteket teremtenek, amelyekben a kiszámíthatóság időnként alacsony, illetve ahol a döntések rendszeres újragondolására van szükség. A posztszocialista országokban a rendszerváltással járó gazdasági átalakulás során a kockázatok lényegesen kevésbé beláthatóvá váltak (Pósfai et al. 2018), párhuzamosan a korábbi állami garanciavállalás és a teljes foglalkoztatottság leépülésével és a piacosítással (Berglof 2015).

A kiszámíthatatlanság, a gazdasági recesszió és az állami szerepvállalás gyors átalakulása a posztszocialista országokban gyakran azt eredményezte, hogy a háztartási stratégiákban fontos szerepet kap az informalitás; ez egyrészt informális gazdasági tevékenységet, másrészt a családi-baráti kapcsolatok fontossá válását jelenti (Pavlovskaya 2004; Ries 1997; Posfai et al. 2018).

A lakásrezsim múködését és változásait értelmezésünk szerint a háztartások és intézmények viselkedése határozza meg a jogi és a fiskális szabályok által definiált részpiac-mátrix keretei között. A lakáspolitika a jogi és pénzügyi feltételek módosítása révén hat a lakáspiaci szereplők viselkedésére - de ez az interakciókat meghatározó tényezőknek csak egyik aspektusa, ahogyan azt a fentebbi elemzésben leírtuk.

\section{A lakáshitel-boom 2000-2007}

A viselkedés motivációi tehát a háttérben álló társadalmi viszonyrendszerektől nem függetlenek, ezért a motivációk kontextusba helyezéséhez a 2000 utáni magyarorszá- 
gi lakáspolitikai és lakáspiaci változásokat és a hozzájuk köthető lakossági/intézményi stratégiákat mutatjuk be.

\section{A hitelboom két periódusa}

A kormányzati szakértők és a lakáspolitikai elemzők jelezték a magyar lakásrendszer korábban bemutatott ellentmondásait, és egyre határozottabban megfogalmazódtak azok a javaslatok, amelyek segítségével a lakásrendszer minél inkább közelíthetett a nyugat-európai modellekhez. A szakértők között konszenzus volt abban, hogy a rendszerváltás után kialakult lakásmodellen a következő három ponton kell változtatni: a szociális bérlakások súlyának növelése, a bérlakásépítés, illetve a tulajdoni lakások építésének, vásárlásának jelzáloghitellel történő finanszírozása. ${ }^{5}$

2000 után a lakáspolitikában fordulat következett, amikor a Fidesz-kormány két komolyabb lakásprogramot indított el: az egyik az önkormányzati bérlakás-állomány növelését célozta meg, a másik a jelzáloghitelezést. ${ }^{6} \mathrm{~A}$ kormányzat lakáspolitikai koncepciója egyértelműen a rendszerváltás okozta torzítások korrigálását túzte ki célul, bár a koncepció maga nem kodifikálódott kormányrendeletben. A tényleges lakáspolitikai döntések (támogatások nagyságrendje, feltételei, jogszabályi változások stb.) azonban már a kormányzati és intézményi érdekek függvényében alakultak. Az igazi konfliktus a banki lobbi és az építőipari lobbi között alakult ki, amelyből a bankok kerültek ki győztesen. Az önkormányzati bérlakás-program nem hozott áttörést a szociális lakáspolitikában, de bizonyította, hogy az önkormányzatok megfelelő finanszírozási feltételek mellett partnerek tudnak lenni a szociális lakáspolitikában. A szociális lakásprogram négy év alatt kevesebb lakással növelte a szociálisbérlakás-szektort, mint amennyi 1998 és 2004 között a „csepegtetett” privatizáció során a szektorból kikerült (Hegedüs 2006). Továbbá az önkormányzati lakásszektor finanszírozási terhei az önkormányzatok saját bevételeit terhelték, így nem lehetett hosszú távú érdekeltséget teremteni a szociálisbérlakás-szektor bővítésében. ${ }^{7}$

A kezdeti nehézségek miatt a türelmetlen politikusok, akik a választási küzdelem fontos elemének tekintették a hiteltámogatásokat, 2002-re olyan mértékben kiterjesztették azokat, hogy gyakorlatilag hosszabb távon fenntarthatatlanná váltak. A 2002-es választásokat megnyerő szocialista-szabad demokrata kormányzat számos demagóg ígéret között (gázárak változatlansága, fizetések emelése stb.) kiállt a lakástámogatások továbbvitele mellett is, ami miatt még két évig pörgött a támogatott lakáshitelezés. A hitelállomány 2000 és 2003 között több mint hétszeresére növekedett, a lakások jelzáloghitel-támogatási programja túl „sikeressé” vált. Négy év alatt

5 Bár ebben az időszakban a kormány nem fogadott el hivatalos lakáspolitikai dokumentumot, belső anyagok egyértelműen tükrözték ezt a trendet (Növekedéskutató Intézet 1999; GM 2000; Otthon Európában 2003).

6 Politikai szempontból fontos program volt az épületállomány felújításához (panelprogram, városrehabilitáció) nyújtott támogatás is, amelyet valamennyi kormányzat politikai okok miatt (választási esélyek javítása) kiemelten kezelt. Tanulmányunkban ezzel a területtel nem foglalkozunk.

7 Érdemes megemlíteni, hogy ezt más posztszocialista ország sem tudta megoldani. Talán a leginkább sikeres program a szlovák volt, amelyben hitelkonstrukció kötelezte a szociális lakások tulajdonosait a költségmegtérülést biztosító lakbérek bevezetésére (Hojsik 2013). 
a lakáshitelek GDP-n belüli aránya 1,1\%-ról 10\%-ra emelkedett, a lakásépítések és a lakástranzakciók száma megugrott, a lakásárak emelkedtek, de lakásár-buborék nem alakult ki (lásd: 1. táblázat).

\section{1. táblázat: Lakáspiaci indikátorok változása 2000-2015}

\begin{tabular}{l|c|c|c|c|c|c|c} 
& $\begin{array}{c}\text { Lakástranz- } \\
\text { akciók } \\
\text { száma } \\
\text { (használt } \\
\text { és új) }\end{array}$ & $\begin{array}{c}\text { Használatba } \\
\text { vett lakások } \\
\text { száma }\end{array}$ & $\begin{array}{c}\text { Kiadott új } \\
\text { építési } \\
\text { engedélyek } \\
\text { száma }\end{array}$ & $\begin{array}{c}\text { FHB- } \\
\text { lakás- } \\
\text { árindex } \\
\text { fogyasztói } \\
\text { árindexszel } \\
\text { deflálva } \\
(\mathbf{2 0 0 0 = 1 0 0 )}\end{array}$ & $\begin{array}{c}\text { Jelzáloghi- } \\
\text { tel-állomány } \\
\text { (december } \\
\mathbf{3 1 . )} \\
\text { Mrd Ft }\end{array}$ & $\begin{array}{c}\text { Devizahite- } \\
\text { lek aránya } \\
\text { (\%) a jel- } \\
\text { záloghitel- } \\
\text { állományon } \\
\text { belül }\end{array}$ & $\begin{array}{c}\text { Jelzálog- } \\
\text { hitel-állo- } \\
\text { mány/GDP } \\
(\%)\end{array}$ \\
\hline 2000 & 183950 & 21583 & 44709 & 100 & 192 & $1 \%$ & $1,4 \%$ \\
\hline 2004 & 171678 & 43913 & 57459 & 135 & 2106 & $1 \%$ & $10,0 \%$ \\
\hline 2008 & 154097 & 36075 & 43862 & 125 & 6507 & $63 \%$ & $23,9 \%$ \\
\hline 2012 & 87957 & 10560 & 10600 & 88 & 5752 & $68 \%$ & $20,0 \%$ \\
\hline 2015 & 134101 & 7612 & 12515 & 99 & 4691 & $64 \%$ & $13,7 \%$
\end{tabular}

Forrás: KSH, FHB-lakásárindex, MNB

A lakáshitelezés felfutásának második időszaka 2004 után kezdődött, amikor is a szocialista-szabad demokrata kormányzat fokozatosan visszafogta (jelentősen csökkentette, de nem szüntette meg) a forinthitelek támogatását, ami azzal a vélt veszéllyel járt, hogy a lakáshitel-piac összeomlik. Ebből az a devizahitelezés, melyet még az első Fidesz-kormány tett lehetővé, jelentett kiutat. Az MNB a magas költségvetési deficit okozta magas infláció csökkentése érdekében kényszerűen magasan tartotta a kamatokat, így a forintkamatok és a devizahitelek kamatai közötti különbség miatt a devizahitel kedvezőbb törlesztési részletet jelentett a hitelfelvevőnek, mint a csökkentett támogatású forinthitel. A szakértők értették a devizahitelek árfolyamkockázatát, de alacsonynak tartották, a forint árfolyamzuhanását pedig valószínútlennek. ${ }^{8} \mathrm{~A}$ devizahitelek gyorsan meghatározó konstrukcióvá váltak: a lakáshiteleken belüli arányuk 2008-ra már 63\%-ra nőtt. Ezt számos tényező segítette: a jövedelmek (a gazdaság teljesítőképességét meghaladó mértékü) emelkedése miatti optimista várakozások, a bankok közötti verseny gerjesztette agresszívebb terjeszkedési politika (ügynökhálózat), a szabad felhasználású jelzáloghitel népszerúsége stb. Ezzel párhuzamosan viszont a kormányzatra nehezedő költségvetési nyomás miatt a szociálisbérlakásprogram leállt, a helyette ígért lakbértámogatás teljes kudarccal zárult, mivel nem vetett számot a lakástulajdonosok elvárásaival (Hegedüs 2006: 95-96). A vállalkozói bérlakásépítés kezdeményezése is érdektelenségbe fulladt, mivel a bérlakás-állomány kezelésének várható kockázatai meghaladták a beruházás révén keletkező profitot. 


\section{Egyéni hitel- és lakáspiaci stratégiák a hitelexpanzió idején}

A 2000-es évek eleji hitelkereslet-növekedés magyarázatát a közgazdászok a rendszerváltás után közel 10 évig tartó recesszió miatt kialakult „fogyasztói türelmetlenségben” látták (Tóth-Árvai 2001). Ugyanakkor a lakásrendszer torz elemeivel is magyarázhatók a hitelfelvétel „furcsa” konstrukciói, mivel az olcsón elérhető hitelek nemcsak a lakások iránti keresletet növelték, hanem különböző befektetési-fogyasztási stratégiák előtt is megnyitották az utat. Alapvetően a következő öt hitelfelvételi motivációt találtunk, melyek múködését interjúink is alátámasztották.

A jelzáloghitelek egy részét fogyasztási célra használták fel, ez kiválthatta a lakásra szánt megtakarításokat is, vagy egyszerűen fogyasztásnövelést tett lehetővé; a szabad felhasználású hiteltermék esetében ez természetesen egyszerúbb volt. Sok esetben váratlan, előre nem tervezett (pl. egészségügyi kiadásokat), vagy bizonyos értelemben a család jövedelméhez képest luxuskiadásokat (tartós fogyasztási cikkek, autó, utazás) finanszíroztak belőle. Az ilyen kevert stratégiák azonban hosszú távon szinte mindig fenntarthatatlan terheket róttak a háztartásokra.

A lakás nemcsak fogyasztási cikk, hanem megtakarítási eszköz is, aminek jelentősége a család életében az életkor függvényében változik. Mivel a magán-bérlakás, önkormányzati bérlakás és a szülőkkel való együttélés egyre elfogadhatatlanabb lakáshelyzetnek számított, ez sokakat tolt a lakásvásárlás felé. A lakásrendszer torzításai tehát a magántulajdont az alternatív megoldásokhoz képest előnyös megoldásnak láttatták. A nyugdíjrendszer kiszámíthatatlanná vált, a lakásvagyonba fektetés az egyéni megtakarítások fontos, kiszámíthatóbb formája lett, elsősorban a középosztályba tartozó családok számára. Egyre gyakoribbá vált ezért a megtakarítási céllal (kiadásra) vásárolt lakás, ahol megfelelő tőkebefektetés mellett (a lakás értékének 20-30\%-a) a bérleti díj fedezte a hitelköltségeket. A családok ugyanis gyakran lakás formájában halmoznak fel tartalékot, ami lehet gondoskodás nyugdíjas éveikre, ahogy erre a vagyonalapú jóléti rendszer (asset-based welfare) elméletei rámutattak (Doling-Ronald 2010), vagy a megtakarítás összegének növelése (ellensúlyozandó az alacsony kamatokat), esetleg a gyerekek lakáshoz jutásának segítése (is).

A vállalkozók esetében nem volt ritka a lakáshitelek beruházási célú felhasználása. A tőkehiányt a háztartások lakóingatlan-fedezetre felvett hitelekkel ellensúlyozták. A vállalkozásokat támogató hitelek felvételéhez ugyanis ingatlanfedezetet kértek, így a döntés kihathatott az adott háztartás lakáshelyzetére, különösen a gazdasági válság beindulásával párhuzamosan romló árfolyam, illetve a gyorsan változó munkaerőpiac miatt. Egy ilyen típusú hitelezés legrosszabb esetben a család lakásának elvesztésével és ezzel a lakhatás korábbi biztonságának megszűntével járhatott.

A szabad felhasználású devizahitelek térnyerése, illetve olcsósága arra csábította a szegényebb családokat, hogy a háztartás jövedelmi deficitjét a lakáshitelekkel orvosolják. Gyakori volt a felhalmozódott hátralékok devizahitellel történő kiváltása, azaz egyfajta adósságrendezési célú hitelfelvétel. Gyakran előfordult, hogy meglévő (forint-) hiteleket (gyakran túlárazott hitelkártyás hitelt) konszolidáltak devizahitellel. 
Ez gyakran bekódolta a bukást, hiszen csak eltolta a csőd időpontját, a strukturális hiányon nem változtatott.

A hitelexpanzió mögötti fenti motivációk szerepét a gazdasági és jóléti rendszer ellentmondásai és a lakáspiac torzításai felerősithették, és egyben jelentősen megnövelhették a háztartások kockázatait, különösen az alacsonyabb státuszú háztartások esetében, amelyek számára korábban a magántulajdonú lakásvásárlás lehetősége nem állt rendelkezésre. Alapvetően három lehetőség között választhattak lakáshelyzetük megoldására:

- a magánbérlakás-szektor mint szükségmegoldás, amely az alulszabályozottság miatt komoly kockázatokkal járt, kiszolgáltatott helyzetet jelentett;

- a piaci lakásállományon belül az alapvetően szubsztandard és/vagy periferiális szféra (tipikus formája a hanyatló térségekben lévő falusias lakás vagy a városszéli, zártkertes területekre való költözés);

- $\quad$ a szülői lakásban maradás, szívességi lakáshasználat.

Nem csodálható tehát, hogy ezek a háztartások többéves magánbérleti „tapasztalat”, vagy a szülőkkel, rokonokkal való (sokszor nem konfliktusmentes) együttélés (I22), ${ }^{9}$ illetve periferikus lakáshelyzetekben eltöltött évek után a fellazult hitelfeltételek elindulásakor szinte „menekültek” a most már számukra is elérhető lakásvásárlásba (I32). Efelé tolták őket a tulajdonláshoz kapcsolódó társadalmi elvárások is, a bérlés negatív megítélése, az, hogy a saját tulajdon a „normálisnak tartott” lakhatási forma, és a bérlés kizárólag átmenetileg fogadható el. Ráadásul általános vélekedés volt, hogy a bérlet kidobott pénz, lényegében a bérleti díjból fizethető a hiteltörlesztés, és a végén még tulajdoni lakáshoz is jut a család (I16, I22). Mindez a lakáshitel felvétele felé tolt sok olyan háztartást, melynek nem voltak meg sem az (anyagi) eszközei, sem a kapcsolati hálóban megtestesülő háttere egy esetleges válsághelyzet kezelésére (I5, I19). A megingott stabilitás visszaszerzését tovább hátráltatta, hogy a családok a lakáshoz vették fel a hitelt, nem pedig a hitelképességüknek megfelelően választották a lakást.

A hitelbírálati feltételek fellazulása, az ügynöki rendszer felügyeletének hiányosságai és az önkormányzatok, majd az építési igazgatás befolyásolhatósága következtében „szabálytalanságok” jelentek meg. Jó példája ennek a miskolci, avasi lakótelepen történt szervezett csalás, ${ }^{10}$ vagy az az eset, amikor egy dunántúli városban egy sokgyermekes roma család úgy vásárolt önrész nélkül 7,8 millió Ft-ért egy lakást, hogy sem a banki ügyintézővel, sem az önkormányzat képviselőjével személyesen nem találkozott (I32).

$\mathrm{Az}$ alacsonyabb jövedelmű családok megjelenése a hitelfelvevők között egyrészt tehát kényszer volt (a szociális helyzetet figyelembe vevő variáns hiánya miatt), másrészt pedig lehetőség, melyet a bankok közötti verseny lazább hitelbírálati rendszere kívánatossá tett.

9 Az l-vel jelzett számok a tanulmányban használt interjúkra vonatkoznak.

10 http://magyarnarancs.hu/kismagyarorszag/vissza-a-gettoba-miskolc-kisopri-a-feszekrakokat-90100. 
Összefoglalva tehát a 2000-es évek elejétől (a támogatások, illetve 2004-től a devizahitel-konstrukció megjelenésével) a kamatok csökkenése, az élesedő bankközi verseny kitágította azon háztartások körét, akik hitelhez juthattak. Egyrészt a makrogazdasági tényezők a lakásnak, mint megtakarítási, vállalkozói hitel biztosítási eszköznek az elterjedését váltották ki. Másrészt olyan családok előtt is megnyitották a magántulajdonú lakásvásárlás lehetőségét, akik számára ez korábban nem volt elérhető. Tehát olyanok is bekerültek a kibővülő hitelpiacra, akik számára a hitelfelvétel túl nagy kockázatot jelentett. ${ }^{11}$

A lakáshitelek megjelenése, különösen a kockázatos devizaalapú lakáshiteleké, a ma nagy népszerúséget élvező financializációs elméletet (Aalbers 2008; Pósfai et al. 2018) látszik alátámasztani. Ezzel szemben a jelzáloghitelek arányának növekedését, ahogy ezt az előzőekben kimutattuk, a lakásfinanszírozási rendszer 1989/1990-es politikai változásokat követő válságból való kilábalásának kísérlete magyarázza, ahogyan erre Pellandini-Simányi és munkatársai (2015) is rámutattak. A lakásfinanszírozási rendszer kockázatait a globális feltételeken túl a lakáspolitikai szereplők (nemzeti bank, kormány, meghatározó bankok stb.) politikája is befolyásolta. ${ }^{12}$

\section{A lakáshitel-válság és következményei 2008-2015}

2008 őszén a pénzügyi válság elérte Magyarországot. A háztartásokra nehezedő, súlyosbodó pénzügyi nyomás közel egymillió háztartást érintett, így a lakáshitel a 2008-2015 közötti időszak egyik legneuralgikusabb társadalmi problémájává vált. A 2008 és 2010 közötti intézkedések követték az addig ismert ortodox válságkezelési módszereket, 2010 után azonban az új kormányzat szakított a hagyományos válságkezelési technikákkal, és radikálisan új megoldásokat vezetett be. Ezeket az unortodox módszereket belpolitikailag a kétharmados politikai többség, külpolitikailag pedig az EU egészét érintő válság tette lehetővé. Az egymásnak ellentmondó intézkedések azt sugallják, hogy nem volt átfogó tervezés, számos irányba indult el a válságkezelés, az intézkedések célja pedig - a gazdaság stabilizálása mellett - a devizahitelek okozta válsághelyzetek társadalmi kezelése volt.

\section{A válság okainak és megoldásának eltérō értelmezései}

A 2004 és 2009 közötti devizahitelezés növekvő gazdasági környezetben játszódott le, ahol a résztvevők (állam, bankok, MNB, lakosság, fejlesztők/építők, közvetítők stb.) mindegyike hasznot húzott a folyamatból, bár a hasznok és a kockázatok nagyon egyenlőtlenül oszlottak meg a szereplők között. Az egyenlőtlenségek a javuló gazdasági környezet miatt politikailag elfogadhatók voltak a szereplők számára: mivel „mindenki jól járt”, ez nem

11 Érdemes megjegyezni, hogy a gépjármúpiacon hasonló trendek játszódtak le: az értékesítési verseny, a lazuló hitelfeltételek és a vásárlói türelmetlenség túlfogyasztást eredményezett: „A kedvezményes hitelkonstrukciók révén olyan társadalmi rétegek is új autóhoz jutottak, amelyek ezek nélkül legfeljebb néhány százezer forintos használt autó megvásárlására lettek volna képesek. Ezeknek a vevőknek a nem jelentéktelen részét a fizetési fegyelme, a pénzügyi normái miatt felelőtlenség volt autótulajdonossá tenni, és a hiteleik már korai szakaszban bebuktak" (Pásztor 2011: 181).

12 Lengyelországban például a devizahitelezés a szabályozás és a bankok konzervatívabb politikája miatt nem ért le az alacsonyabb jövedelmú csoportokig (Augustyniak et al. 2019). 
okozott konfliktusokat. Az egyenlőtlen pozíciók a lakáshitelezés intézményi-hatalmi viszonyai között alakultak ki, strukturális és egyedi tényezók együtthatásának eredményeként. A különböző szereplők egyetértettek abban, hogy a forinthitelnél sokkal olcsóbbak a devizahitelek, amelyek árfolyamkockázatával komolyan nem kell számolni. A bank egyoldalú kamatemeléssel (és díjmeghatározással), valamint a hitel mögötti ingatlanfedezettel biztosítja helyzetét; az adós a törlesztés fizetését el tudja vállalni (feltételezve, hogy egyéni helyzete nem romlik), az államnak nem kell plusztámogatást nyújtania, a pénzügyi szabályzórendszernek (MNB és felügyelet) nincs oka beavatkozni, azon túl, hogy mindenkit figyelmeztet a tankönyvi kockázatokra. ${ }^{13}$ Ezek az elemek a lakásfinanszírozási rendszer egységes felfogását testesítették meg, azaz a szereplők többé-kevésbé azonos logika alapján alakították ki stratégiájukat. Az egységes megközelítés mögött ugyanakkor nagyon különböző pozíciók és magatartások húzódhattak meg.

Két összefüggést, rendezőelvet emelnénk ki, amelyek az egyes szereplők pozícióját és választott stratégiáját befolyásol(hat)ták: az információs aszimmetriát és az erkölcsi kockázat (moral hazard) problémáját. A hitelfelvevők tipikusan nem rendelkeztek azokkal az információkkal, amelyek alapján a árfolyamkockázatot fel tudták volna mérni, így kiszolgáltatottságuk nagy volt. A várható kockázatokkal kapcsolatban az állami szervek és a média sem rendelkezett egyértelmú állásponttal; lényegében azzal érvelt, hogy van kockázat, de minimális. Egyes bankok esetében felvethető az erkölcsi kockázat problémája, amennyiben úgy gondolkodtak, hogy ha komoly, rendszerszintű válság lesz, az államnak be kell lépnie az adósok oldalán, azaz a lazább hitelbírálati kritériumok következményei átháríthatók lesznek az államra. Papíron tájékoztattak, de a közvetítők pénzügyi érdekeik miatt visszaélhettek az információkkal, vagyis a két szereplő érdekeltsége, és így stratégiája, eltérő lehetett.

A 2008-as válság Magyarországot nagyon súlyosan érintette, aminek alapvető oka a makrogazdasági egyensúly megbomlása, a felelőtlen fiskális politika és a devizahitelezésen keresztüli, a fundamentumokkal nem alátámasztott fogyasztási színvonalemelés volt. Az árfolyamváltozás miatt a devizahitellel rendelkezők törlesztőrészletei oly mértékben nőttek meg, hogy sokan nem voltak képesek (nem tudtak/nem akartak) teljesíteni (Dancsik et al. 2015). A helyzetet tovább súlyosbította a munkanélküliség növekedése, a jövedelmek csökkenése. Ráadásul az állam a szociális kiadásokat (beleértve a lakástámogatásokat) visszafogta, miközben a bankok viselkedése (kamatés díjemelési politikán keresztül) tovább növelte a szociális problémákat. A devizahitelezés egységes felfogása összeroppant, a különböző szereplők saját egyéni érdekeik és politikai törekvéseik alapján kidolgozták a saját (új) álláspontjukat. Társadalmi konszenzus hiányában a párhuzamos, egymásnak ellentmondó értelmezések a válság elhúzódását és elmélyülését eredményezték, mert minden szereplő a saját érdekeinek megfelelő stratégiát követett, ami szükségképpen növelte a megoldás költségeit.

13 „A Járai Zsigmond vezette MNB a magas kamat politikájával erősítette a forintot, emellett az elnök több nyilatkozatában is egyenlőségjelet tett az erős gazdaság és az erős forint közé. A gyors euróövezeti csatlakozás eufóriájában nehéz is lett volna a mindenki számára elönyös euróhitelek ellen ágálni - nem is volt, aki ezt tette volna, sem az üzleti, sem a politikai, sem a szakértői körökben" (Várhegyi 2010). 
A hitelválság költségeit négy szereplő között lehetett volna megosztani: az állam (azaz adófizetők), a banki részvényesek, a banki ügyfelek és a hitelfelvevők között. Mivel a „felelősök” nem azonosíthatók, a hitelválság költségeinek elosztása politikai alku kérdésévé vált, ami nem segítette, sok esetben inkább hátráltatta a hitellel rendelkezők optimális stratégiájának kialakítását. A megoldást kereső szakértői viták alapján három főbb értelmezési irányzat jelent meg:

1. A hitelfelvevőké a felelősség: A devizahiteleseket nem kell megmenteni, egyértelmű, hogy a szerződésekben ők vállalták az árfolyamkockázatot, aminek előnyeit az erős forint időszakában élvezték, így indokolatlan az árfolyamgyengülés költségeit átvállalni.

2. A felelősség megoszlik: A devizahitelezés felelőssége megoszlik a szereplők között, ezért olyan megoldásokat kell találni, amelyek a társadalmi költségeket fair módon osztják meg a szereplők között.

3. A hitelfelvevőket semmilyen felelősség nem terheli: A devizahitelezés a tájékozatlan fogyasztók becsapására épült, ezért a károsultakat teljes mértékben kárpótolni kell, a költségeket fizessék a bankok és az állam.

Az első álláspontot legélesebben Csillag István és Mihályi Péter fogalmazták meg, akik nem látták indokoltnak programok indítását (2011). Ezt részben gazdasági/lakáspolitikai megfontolásokkal magyarázták: a korszerű gazdaságpolitika újra megerősíti majd a forintot, és ez szükségtelenné teszi a beavatkozást. A befagyott lakáspiac megmozgatása jót tesz a lakásrendszernek, el kell kerülni az állami és önkormányzati lakástulajdonosi szerepvállalás növelését. Másrészt pedig szociális megfontolások miatt tartották szükségtelennek a beavatkozást: úgy látták, hogy alapvetően a középréteg problémájáról van szó. A családgazdálkodási modellek, azaz intergenerációs transzferek miatt a rászorultak nem azonosíthatók, így a programok nem célozhatók hatékonyan. Ezt a véleményt többen osztották, amiben nem kis szerepet játszott az elemzők értékelése. Gáspár és Varga (2011) - a háztartás költségvetési felvételre épülő - elemzése alulbecsülte a probléma súlyát, nagyságrendileg 60-70 ezer háztartás érintettségét és egy-két éven belüli radikálisan javuló helyzetet prognosztizált. Ekkor még az MNB-jelentések is kezelhetőnek tekintették a válságot és a problémákat. Sőt, a szociális szakma képviselői is ellentmondásosnak tartották a devizahitelesek megmentését.

A második álláspontot nagyon sok, a különböző szereplők felelősségét mérlegelni próbáló közgazdasági elemzés tárgyalja. A 2010-ben felállított parlamenti bizottság jelentése (meglepetésre) olyan kiegyensúlyozott elemző anyagot készített a parlament részére (OGY 2012), amely szereplőnként összegyüjtötte az érveket, ami alapján a felelősség megállapítható. Az anyag és az azt megelőző, illetve követő vita nem adott egységes értelmezést a folyamatra, sokkal inkább egymáshoz nem szorosan kapcsolódó tényezők felsorolásáról volt szó. Meghatározó álláspontot képviselt Surányi (2010, 2015), aki a kormány kiemelt szerepe mellett (elhibázott fiskális politika) az MNB felelősségét hangsúlyozta, ugyanakkor érvelésében az MNB-től olyan lépéseket hiányolt, amelyek nem tartoztak jogilag és elméletileg sem az MNB 
feladatai közé, ahogyan ezt Pete Péter (2010) és Obláth Gábor (2010) is szóvá teszik. ${ }^{14} \mathrm{~A}$ vita alapvetően azon volt, hogy mekkora a kormány (azon belül az 1998-2002-es Fidesz vagy a 2002-2010-es MSZP-SZDSZ), az MNB, az egyedi bankok, illetve a lakosság felelőssége; mit kellett volna tenni, hogy a válság elkerülhető legyen. A nagy vita ellenére a különböző elemzők egyetértettek abban, hogy indokolt megosztani a devizahitel-válság költségeit a szereplők között.

A harmadik álláspont kulcsfigurája Róna Péter volt, aki bevezette a „hibás termék” fogalmát, teret adva annak az álláspontnak, amely a hitelfelvevők felelősségét teljes egészében a bankokra és a bankokat nem kontrolláló államra helyezi. Róna (2013) érvelése részben a hitel jogi definíciójának szélsőséges (nem egyértelmű) értelmezésére támaszkodott, részben pedig egy hibás közgazdasági megállapításra. Ez utóbbival kapcsolatban megjegyezhető, hogy a valóságban a hitel (legyen az fix vagy változó kamatozású stb.) mindig tartalmaz bizonytalanságot, azaz a felvett hitelhez képest a törlesztések jelenértéke eltérhet a makrogazdasági feltételek függvényében (infláció, kamat, gazdasági növekedés). Természetesen a kockázatok nagysága és megosztása a hitelező, a hitelfelvevő és az egyéb szervezetek (állam, garanciaintézmény stb.) között termékenként változik, de nincs olyan hiteltermék, amely mentes lenne a kockázatoktól. A „hibás termék” fogalma mögött nem jogi vagy közgazdasági, hanem politikai megfontolások voltak: egy párt ideológusának a törekvése a közpolitika befolyásolására. Hasonlóan érvel Lentner Csaba (2015), és szakmailag megalapozottabban Bethlendi (2015). Mindenesetre ez a megközelítés népszerű lett, s a közmédia, a politika és a hiteles érdekcsoportok is átvették, ${ }^{15}$ hiszen a bankellenes álláspontot alátámasztani látszott (Szabó 2018).

A különböző devizahitel-mentési akciók mögött fellelhetők a fenti alternatív megközelítés elemei. Kis leegyszerúsítéssel azt mondhatjuk, hogy a Bajnai-kormány kísérletei mögött alapvetően az első értelmezés húzódott meg. Az Orbán-kormány akciói politikai érdeke függvényében a második megközelítés különböző variációival játszottak, míg a „társadalmi mozgalmak” alapvetően a harmadik megközelítést vallották magukénak. Mindez jelentős mértékben járult hozzá a válság elhúzódásához és a bajba jutott hitelesek döntésképtelenségéhez. Más posztszocialista országokban (pl. Észtország, Litvánia) a helyzetet konzekvensen és egyszerűen kezelve a válság időszakát gyorsabban sikerült lezárni.

\section{Adósmentő programok dinamikája}

A 2008-as válság hatása fokozatosan jelent meg a jelzáloghitel-rendszerben. Az elemzők alulértékelték a válság veszélyét, amit jól jeleznek az akkor publikált MNB-jelentések és a kapcsolódó publikációk (Gáspár-Varga 2011; MNB 2009). A 90 napon túli hátralékos jelzáloghitelek aránya 2008. december és 2009. december között 3,5\%-ról 7,5\%-ra növekedett (MNB 2010), de ebből a szempontból Magyarország nemzetközi

14 A történethez hozzátartozik, hogy a Surányi által irányított bank az egyik legaktívabb devizahitelező intézet volt, ami mutatja, hogy az ex post elemző funkció és az aktív szereplő viselkedése nem feltétlenül van harmóniában.

15 Maga Róna közpolitikai javaslatokban mérsékeltebb volt, nem támogatta az egyoldalú, bankokat sújtó megoldásokat. 
összehasonlításban nem tartozott a legrosszabb helyzetúek közé; Lettországban például 2009-re már 10\% felett volt ez az arány (Erbenobva et al. 2011).

A helyzet kezelésére a Gyurcsány-kormány komoly programot nem indított, intézkedései mögött nem volt sem igazi politikai szándék, sem forrás. Lényegében a korábban említett első értelmezést fogadta el, amely sajnálatosnak tekintette a hitelfelvevők helyzetének romlását, de alapvetően a felelősséget a meggondolatlan, kockázatokkal nem számoló hitelfelvevőkre hárította. A lakosság ekkor kezdett szembesülni a törlesztőrészletek radikális emelésével, amit nemcsak az árfolyamváltozás, hanem a hitelkockázat kamatokba való beépítése is okozott. A bankok a korábbi tapasztalatok birtokában nem voltak óvatosak, és kihasználták az egyoldalú kamatdöntés adta lehetőségeket, számítva arra, hogy a tömeges bedőlések esetén az állam, ahogy eddig is tette, közbe fog lépni.

A 2010-es kétharmados támogatást élvező Orbán-kormány unortodox társadalomformáló céljaiba beleillett a bankszektorral való konfrontáció (Várhegyi 2018), amely elvárásaiknak megfelelően alkalmat adott a banki struktúra átalakítására („hazai bankok" 50\% feletti részesedésének elérése). Az Orbán-kormány alapvetően a (fent leírt) második álláspont mellett foglalt állást, ami tág teret adott a gazdasági felelősség politikai szándékok szerinti finomhangolására. A kommunikációban gyakran átvette a radikális ellenzék érveit, de programjaiban a játékszabályokat - azaz a terhek megosztásának szabályait - jóval kevésbé múködtette e szerint.

A 2010 és 2016 közötti lakáspolitikát a deviza-, illetve jelzáloghitelek miatti társadalmi konfliktusok kezelése jellemezte, ennek keretét a 2011-es törvény akcióterve jelentette. ${ }^{16} \mathrm{~A}$ különböző programok közös jellemzője volt, hogy - bár a kormány erőből tárgyalt az érintett szereplőkkel (bankokkal, adósokkal és az őket képviselő szervezetekkel) - a program részleteinek kialakításában és megváltoztatásában meszszemenően figyelembe vette a piac reakcióit. Ugyanakkor a programoknak a lakásszektoron is túlmutató politikai törekvései voltak, többek között a bankok közötti erőviszonyok újrarendezése, ${ }^{17}$ a középosztály anyagi pozícióinak konszolidációja, a legrászorultabbak pacifikációja, és az alternatív mozgalmak politikai semlegesítése.

A programok közül a végtörlesztés volt a válságkezelés egyik legellentmondásosabb intézkedése (2. táblázat). A stabil jövedelmi helyzetben lévő hitelfelvevők kivezetését célozta, ami - ellentmondva az alapvető szociális értékeknek - rászolgált az unortodox jelzőre, és komoly piaci veszteségeket okozott a bankszektornak. A devizahitellel rendelkezők 18\%-a élt a lehetőséggel. A program - amely 170 ezer szerződést érintett, és 15-20\%-át a jelzáloghitellel rendelkező családoknak - kedvezményes árfolyamon tette lehetővé a devizahitelek egyösszegű visszafizetését 2011 szeptembere és 2012 februárja között (PSZÁF 2012). A végtörlesztés 300 Mrd forintos (a bankadó mérséklését figyelembe véve 200 Mrd Ft-os) veszteséget jelentett, ez adósonként átlagosan 1,7 mil-

162011 LXXV. törvényben megjelennek a devizamentési programok fôbb elemei, mint a kényszerértékesítés szabályozása, az árfolyamgát, a forintosítás egy „puhább” verziója, de a törvény gyakori módosításai jól jelzik a politika bizonytalanságát.

17 Nem célja a tanulmánynak, és nincs is módunk rá, hogy a kormány és a bankok közötti alku részleteit feltárjuk, de az valószínűsíthető, hogy a kormány sikeresen használta ki a bankok közötti ellentéteket. Kacérkodott a legnagyobb bank (OTP) pozícióinak gyengítésével (az FHB és a Takarékbankok megerôsítésének kísérlete), amit a végtörlesztés során megjelent konfliktusok tanúsítanak. 
lió Ft (GKI 2015). Tipikusan a magasabb státuszú rétegeknek nyújtott valós segítséget, hiszen ők rendelkeztek elegendő forrással a végtörlesztéshez. A kormány mindent bevetett, hogy a végtörlesztők száma növekedjen: a takarékszövetkezeteket sikeresen ösztönözte arra, hogy hitelt nyújtsanak a végtörlesztők számára, az adóhatóság eltekintett a végtörlesztés során előteremtett pénz forrásainak ellenőrzésétől, az állami intézményeket, vállalatokat ösztönözték arra, hogy vállalati hitelt nyújtsanak, a bankokat megfenyegették, hogy ha szabotálják a folyamatot, büntetésre számíthatnak. ${ }^{18}$

Egyértelműen sikeres program volt, és élvezte a bankszövetség támogatását is a bedőlt hitelek Nemzeti Eszközkezelő (NET) révén történt felvásárlása, illetve a bérlakáskonstrukció kialakítása. Az állam az eszközkezelő cégén keresztül megvásárolta a bajba jutott hitelesek lakásait, akik alacsony lakbér mellett bérlőként a lakásban maradhattak. A NET-program keretében mintegy 36 ezer lakás kerülhetett állami tulajdonba. ${ }^{19}$ Jól mutatja a programok improvizatorikus jellegét, hogy a részvételi jogosultság és a múködési feltételek folyamatosan változtak, így a kezdeti 5 ezres lakáscél 35 ezerre nőtt, és még ma is vannak javaslatok a keret további bővítésére. A program teljes költségét nehéz megbecsülni, de hozzávetőlegesen 150 Mrd Ft-ba került, azaz háztartásonként 4,2 millió Ft-ba.

$\mathrm{Az}$ a köztes szociális helyzetú réteg, amely sem a végtörlesztéshez nem rendelkezett elegendő erőforrással, sem a NET-program szigorú feltételeinek nem felelt meg, nem kapott hatékony segítséget, és közülük sokan lakásvesztéssel nézhettek (néznek) szembe. 2018-ra csökkent a nem teljesítő lakáshitelek száma és aránya, de ennek egyik oka az volt, hogy követeléskezelők vették át a „rossz” hiteleket.

2. táblázat: A devizahitelesek helyzetét segítő kormányzati és nem kormányzati programok

\begin{tabular}{|c|c|c|c|c|c|}
\hline \multirow{3}{*}{$\begin{array}{l}\text { Társadalmi } \\
\text { rétegek }\end{array}$} & \multicolumn{3}{|c|}{ Kormányprogramok } & \multirow{3}{*}{ Bankok } & \multirow{3}{*}{$\begin{array}{c}\text { Alternatív } \\
\text { mozgalmak, } \\
\text { programok }\end{array}$} \\
\hline & \multicolumn{2}{|c|}{ rétegspecifikus } & \multirow{2}{*}{ egységes } & & \\
\hline & sikeres & sikertelen & & & \\
\hline Felső & $\begin{array}{c}\text { Végtörlesztés } \\
\text { (2011) }\end{array}$ & \multirow{2}{*}{$\begin{array}{l}\text { MNB civil bank } \\
\quad(2012)\end{array}$} & \multirow{3}{*}{$\begin{array}{l}\text { Elszámoltatás } \\
\text { (2014); } \\
\text { forintosítás } \\
(2015)\end{array}$} & \multirow{2}{*}{$\begin{array}{c}\text { Hitelek átstruk- } \\
\text { turálása (fo- } \\
\text { lyamatos } 2008 \\
\text { után) }\end{array}$} & \multirow{3}{*}{$\begin{array}{c}\text { Perek, tilta- } \\
\text { kozás, NGO- } \\
\text { programok } \\
\text { (folyamatos } \\
2008 \text { után) }\end{array}$} \\
\hline Közép- & $\begin{array}{c}\text { Árfolyamgát } \\
(2012)\end{array}$ & & & & \\
\hline Alsó & $\begin{array}{l}\text { Nemzeti Eszköz- } \\
\text { kezelő (2012); } \\
\text { moratórium } \\
\text { (2009 és } 2014 \\
\text { között) }\end{array}$ & $\begin{array}{l}\text { Ócsa (2014); } \\
\text { magáncsődtör- } \\
\text { vény (2015) }\end{array}$ & & $\begin{array}{l}\text { Követeléskeze- } \\
\text { lők bevonása } \\
\text { (2015 után) }\end{array}$ & \\
\hline
\end{tabular}

Forrás: Saját szerkesztés

18 A GHV 2012 elején több banknál is vizsgálatot tartott, mert tevékenységüket kartellgyanúsnak vélték. A Fundamenta Lakástakarék Pénztárt is komoly büntetéssel fenyegették meg, mert úgy vélték, hogy nem eléggé nyújtott takarékpénztári hiteleket a végtörlesztésre, pedig a pénztár volt a kormány új lakáspolitikájának az egyetlen komoly támogatója, amit jól mutat, hogy a 2010-ben újra megalakuló Lakáspolitikai Tanácsadó Testület munkáját a Fundamenta bank szakemberei szervezték és adtak helyet a találkozóknak.

19 https://infostart.hu/gazdasag/2017/06/14/uj-lakasokat-vehet-at-az-eszkozkezelo. 
E két programon túl számos más „beavatkozás” érintette az adósok helyzetét. Ilyen volt az árfolyamgát, amelynek finanszírozása szintén alapvetően a bankokra hárult (kevésbé volt átütő siker, bár a bankoknak is egyértelműen előnyös volt) vagy a kilakoltatási moratórium, majd a kvóták, az ócsai lakótelep-kísérlet (mely 80 lakás után leállt, 33 millió Ft/lakás költséget okozva). A kúria döntése alapján történt elszámolás, a magáncsőd megjelenése (mely többéves előkészítés után lépett életbe, ám kevesebb, mint ezer esetben hozott megoldást), valamint a kötelező konverzió. Ezek a programok komoly szakmai visszhangot váltottak ki, a bevezetés és végrehajtás során is folyamatosan változtak - egyrészt az általuk okozott konfliktusok következtében, másrészt a szereplők stratégiáinak módosulása miatt.

A lakáshitellel rendelkező háztartások aránya 2000 és 2008 között 7,5\%-ról (2001) 15\%-ra (2007) emelkedett (Medgyesi 2008). A jelzáloghitellel rendelkező háztartások aránya 2010-ben 19\% volt (KSH 2011). A statisztikai adatok alapján nehéz pontos képet kapni az egyes programok által érintett háztartások számáról. Becsléseink ${ }^{20}$ szerint a 2009-ben jelzáloghitellel rendelkező háztartások (850 ezer) 60\%-ának sikerült alkalmazkodnia komolyabb veszteség nélkül, 40\%-uk azonban komolyabb veszteséggel számolt (vagy kell számolnia) (lásd 3. ábra).

\section{3. ábra: A különböző megoldásokban részt vett háztartások becsült aránya}

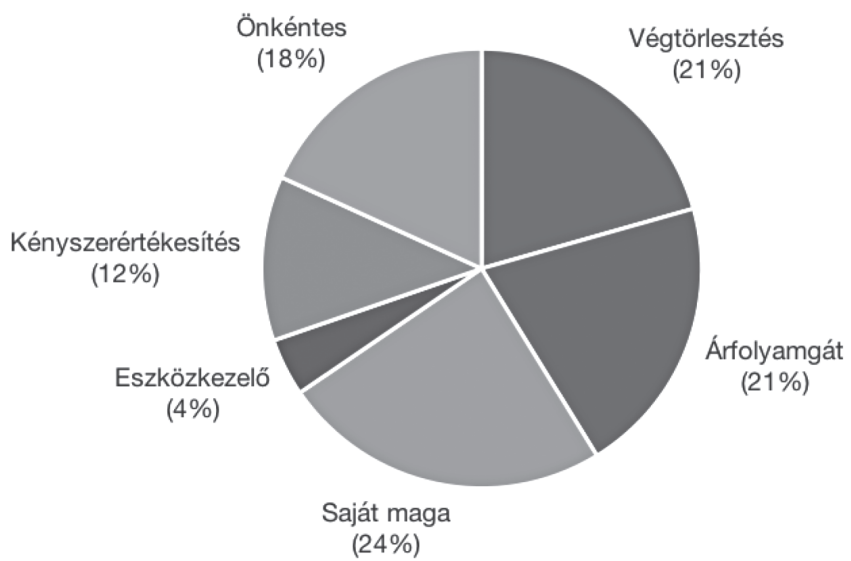

A devizahitelesek problémája a média fontos témája volt, és a 2009 és 2015 közötti kormányzati intézkedések határozatlansága miatt háztartások tömegei váltak tanácstalanná. Gyakran életük legfontosabb pénzügyi döntését kellett meghozniuk, amikor

20 A teljes jelzáloghitel-állományra vetítettük a programokat, más elemzések csak a devizahitel-állományra. Király (2019) könyvében 400 ezerre becsüli a devizahitelesek számát. A mi elemzésünk szempontjából a fizetési nehézségekkel küzdő forintalapú jelzáloghitel is része a problémának. 
a kormány által „felkínált” programok között választottak, ám nem volt egyértelmű, hogy mikor célszerű döntést hozniuk, hiszen úgy tűnt, újabb és újabb programok indulnak: sokaknál a halogatás hátterében a jobb alternatíva várása állt.

A bizonytalanságot tovább növelték a különböző mozgalmak, amelyek a jogi és közgazdasági alapokat nélkülöző érvekkel alátámasztott elképzelésekkel gyakran irreális reményeket ébresztettek. Ebben a helyzetben, szoros összefüggésben a radikális mozgalmakkal, indultak meg a peres eljárások, amelyekre a kormányzatnak a kétharmados parlamenti támogatás ellenére nem volt közvetlen befolyása. Ugyanakkor a tömeges perek azzal fenyegették a kormányt, hogy elveszti a diskurzust meghatározó pozícióját, ezért lépéskényszerbe került: a kissé ellentmondásos Kúria jogegységi határozat és a kapcsolódó elszámolási törvény volt a megoldás, kifogva a szelet a radikális mozgalmak vitorlájából. Komoly változást a devizahitelekben a forintosítás jelentett, ami (bár vezető MNB-szakértők ezt korábban nem tartották értelmes megoldásnak ${ }^{21}$ a jó időzítés miatt valóban nagy segítséget jelentett, és lényegében az egész kérdést más politikai dimenzióba helyezte.

A bankok meggyengült politikai pozícióban vészelték át ezeket az éveket, bár veszteségeiket a díjak növelésével részben áthárították a fogyasztókra (lényegében a jobb anyagi helyzetben lévőkre), és a hitelek átstrukturálásával enyhítették a probléma súlyát, illetve a követelések értékesítésével a politikai felelősségétől is megszabadultak, de mindent együttvéve az ,adósmentési akciók” jó pár évig elhúzták a válságot, és a bankok csak 2015 után váltak képessé bekapcsolódni a hitelezésbe.

\section{A háztartások „válaszai” a hitelválságra}

A 2000-es évek első felében a lakáshitelt felvevők még a magasabb jövedelmú csoportokból kerültek ki (Bethlendi 2009). A felső jövedelmi ötödbe tartozó személyek az átlagnál közel ötször nagyobb valószínűséggel, közel húsz százalékkal nagyobb összegű támogatást vettek fel (Hegedüs 2006: 85). Viszont 2004 után, a hitelezési piac felfutásával a társadalmi összetétel megváltozott: megnőtt a hitelfelvevők között azon rétegek aránya, akik forinthitel esetében nem lettek volna hitelképesek, vagy csak sokkal kisebb összegekre. Ezt támasztják alá a KSH 2011-es adatai is: a lakáscélú jelzáloghitellel rendelkezők aránya 8,1\% volt az alsó és 14,1\% a felső jövedelmi decilisben. A szabad felhasználású jelzáloghitellel rendelkezők esetében viszont ez az arány már megfordult (18,2\% és 7,9\%) (KSH 2011). Ezek a háztartások olyan élethelyzetekben is a lakásvásárlást választották, amikor egyébként (egy jól működő lakásrendszerben) támogatott vagy kontrollált lakásbérlet, illetve egy rövid távú gazdasági változásoknak nem kitett szövetkezeti megoldás megfelelőbb lett volna. ${ }^{22} \mathrm{Az}$ átlagos jövedelmú,

21 Balás és Nagy (2010) azzal érvelnek, hogy a konverzió csak a kockázatokat strukturálja át, Király (2019) új könyvében pedig azzal, hogy a végtörlesztés előtti idöszakban nem is áll rendelkezésre elegendő devizatartalék. Megjegyezhető, hogy az MNBelnök (Matolcsy György) és a Nemzeti Fejlesztési Minisztérium (Varga Mihály) nyilatkozatai 2012 körül is egyértelműen kijelentették, hogy konverzió nem lesz.

22 Ezek a 2000-es években már és még nem létező alternatívák lehetővé teszik a háztartások rugalmasabb alkalmazkodását a megváltozó munkaerőpiaci, lakáspiaci és egyéni családi feltételekhez. 
pénzügyi tartalékokkal rendelkező családi háttér hiányában a hitel olyan lehetőségnek tűnt, amellyel (megfelelő méretű) saját tulajdonú lakást szerezhetnek. Döntésüket alapvetően befolyásolta, hogy nem léteztek alternatívák sem a szociális-, sem a magánbérlakás-szektorban. Tanulmányunk utolsó, empirikus adatokat feldolgozó fejezetében éppen ezen csoport stratégiáit fogjuk elemezni.

A hitelekkel rendelkező háztartások törlesztési gondjait a 2008-as gazdasági válság okozta, és három egymástól nem független tényezőre lehet visszavezetni: a munkaerőpiaci helyzet romlása (I11, I12, I13, I14, I16, I19, I22), a törlesztőrészletek emelkedése és az egyéni háttér romlása, mint például a családi/rokoni kapcsolatok instabillá válása (I21), vagy az egészségügyi helyzet romlása (I10, I22). Ezeket az okokat a nem teljesítő hitelek részletes elemzése hasonlóképpen látta (Dancsik et al. 2015).

Ugyanakkor a háztartások helyzetét tovább rontotta az a körülmény, hogy a politika ellentmondásosan reagált a válságra. Még a racionálisan viselkedő háztartások (akik realizálva a pénzügyi nehézségeket, tudatosan választották meg a számukra legjobb kiutat) sem látták világosan (I6, I13), hogy a korábban felvázolt három, egymással ellentmondásban lévő értelmezés közül melyik alapján alakítja ki a kormány a stratégiáját (I11). ${ }^{23}$ A háztartások tipikusan halogatták a döntéseket, mert mindenképpen meg akarták tartani a lakásukat, és abban reménykedtek, hogy még jobb ajánlat, számukra kedvezőbb megoldási konstrukció jöhet a helyzet kezelésére (I5, I19). Sokszor az oktatási-kulturális háttér hiányosságaiból is fakadt, hogy a családok nem reagáltak időben, igyekeztek nem szembenézni a háztartás csökkenő fizetőképességével (I14). A halogatás vagy éppen ennek ellentéte, a kapkodva meghozott rossz döntések önmagukban tovább nehezítették a helyzetet. Ráadásul olyan mértékben voltak képesek felborítani a családi egyensúlyt, ami teljes csődbe juttathatta a családot (I7, I12, I15, I16).

A háztartások ezekben a helyzetekben sokszor nem viselkedtek racionálisan (I10, I11). Amíg a hitelfelvétel esetében döntéseikben az ismert mintákra és a közvetítők tanácsaira hagyatkoztak, amelyek egy egységes logikát követtek, addig az egyéni válságra nem álltak készen jó megoldásaik. A késlekedés önmagában növelte a válság súlyosságát. Sok háztartás esetében az önálló tulajdonú lakáshoz jutás a lakásrezsim hátrányos pozícióiból való kitörést jelentette, amihez mindenáron, az irracionalitás határát súrolva is ragaszkodtak (I5, I30). Ezek a családok a válság következményeként elóállt helyzetet nem akarták elfogadni, az újonnan megszerzett lakásukhoz a végsőkig ragaszkod(hat)tak, miközben a bérlést teljesen elutasították (I19).

Amíg a munkajövedelmek csökkenése (munkaerőpiaci pozíció) és a törlesztőrészletek emelkedésének hatása egyértelmű, addig a családi/rokoni kapcsolatok szerepe többféle lehetett. A jóléti rendszerekkel foglalkozó irodalom (Ferrera 1996) a családi-rokoni-baráti kapcsolatoknak pozitív (egyenlőtlenségeket/hátrányokat mérséklő) funkciót tulajdonít. Válság esetében azonban a szoros kapcsolatok sokszor inkább kockázatokat jelentenek, aminek a következményeit nemcsak a nukleáris

23 Érdemes megjegyezni, hogy a hasonlóan magas devizahitel-állománnyal rendelkező országokban a kormányzatok sokkal gyorsabban és egyértelmúbben reagáltak a válságra (Bohle 2014; Erbenova et al. 2011). 
család, hanem a rokoni/családi kör vétlen tagjai is viselik (I10) - gyakran inkább ragadja magával a családot-rokonságot a bizonytalanságba, mintsem segítene onnan kiemelni (I22). A bajba kerülés nem csak a nukleáris családot sújthatja. Mivel a hitel felvételéhez gyakori a családi segítség (pl. más családtag lakására került jelzálog), ezért a hátralékba kerülés a tág családot is akár több évre rossz helyzetbe sodorhatja (I32).

A hitel törlesztőrészletének folyamatos emelkedésére és a kialakult válsághelyzetre adott reakciókat hat típusba sorolhatjuk: ${ }^{24}$

1. Visszaköltözés a szülőkhöz és a lakás kiadása (I18)

A megnövekedett törlesztőrészlet fizetésének egyik módja az ingatlan kiadása, és valamely családtaghoz költözés. Ez főleg a szülőkhöz visszaköltözést jelenti, de időnként a fordítottjára is van példa (az újonnan vásárolt lakásba költözik be az egész család, és a szülői lakást adják ki). Ez a stratégia legtöbbször sikeres, azok élnek vele, akik a törlesztőrészletet önerőből nem tudják már fizetni, ám a lakáshoz ragaszkodnak. Mivel végtörleszteni nem tudnak, de általában olyan háttérből érkeznek, ahol van bizonyos tartalék, pl. a szülői ingatlan mérete lehetővé teszi ezt a döntést, a lakás megtartása csak bérbeadással lehetséges. Vagyis életvitelüket jelentősen módosítani kell, gyakran korábbi életvitelük gyakorlatához térve vissza.

2. Lemondás a lakásról, albérlet vagy periferikus lakáshelyzet (I5, I14, I15, I19, I26, I33)

Igen drasztikus és csak végső megoldásnak látják az interjúalanyok, amikor a helyzet csak a lakásról való lemondással oldható meg. Különösen fájdalmas ez abban az esetben, amikor a lakás megvásárlásához nem csak a nukleáris, de a tágabb család is áldozatot vállalt (pl. a szülői lakásra került a jelzálog). Ilyenkor a tágabb család stabilitása is veszélybe kerül, és a kiegyenlítésnek, helyrebillentésnek már nem járható módja a szülői segítség. Nem marad más hátra, mint az albérletbe kényszerülés vagy olcsó (gyakran a korábbi lakhatásnál rosszabb, periferikus helyen lévő) lakásba való költözés (pl. zártkert I33).

3. Lemondás a lakásról, szülőkhöz, rokonokhoz visszaköltözés (I4, I16, I30)

Az előzőnél valamivel jobb a helyzet, amikor a lakás elvesztése nem jelenti a tágabb család meggyengülését. Ilyen esetekben a szülők nyújtják a lakhatás biztonságát, még azon az áron is, hogy az ő komfortjuk jelentősen csökken. Igen gyakori, hogy a saját lakásba költözött fiatalok gyerekes családként térnek vissza a korábbinál nem nagyobb lakrészbe.

4. Minden erőforrás mozgósítása jelentős anyagi áldozat árán, a lakás megtartásával (I7, I8, I9, I10, I12, I17, I22, I28, I29)

24 Azokat az interjúalanyainkat, akik nem kerültek bajba, vagy bajba kerültek ugyan, de segítséggel másik saját tulajdonú lakáshoz jutottak, vagy végrehajtás alatt álltak és még nem volt látható a helyeztük változásának iránya, a mellékletben közölt 3. számú táblázatban jelöltük ugyan (7,8), de a tipizálásnál nem vettük figyelembe. 
Sok háztartás a lakás megtartása érdekében a család erejét meghaladó áldozatot vállal, még saját fogyasztásának drasztikus visszafogásával is párosítva. Sok esetben tartalékok, baráti vagy rokoni kölcsönök, életbiztosítás vagy nyugdíjcélú megtakarítások felhasználásával tudják valamennyire rendezni a helyzetet. Időnként öröklés, vagy gépkocsi, telek stb. értékesítése is szerepet kap, mely a háztartás lakáskarrierjét-lakásmobilitását évtizedekre ezen a ponton fagyasztja be. Ilyenkor a kiadások minimalizálása és az életszínvonal csökkenése jellemző. A talpra állásnak tehát igen nagy, a következő generációra is kiható hatása lehet. Ugyanakkor főleg a fiatalok esetében - akik még rugalmasabbak, és úgy látják, hogy az életben sokféle lehetőség, út áll előttük - fordul elő, hogy inkább lemondanak a terhelt örökségről, az adóssággal terhelt lakásról, csak szabaduljanak a csapdahelyzetból.

5. Külföldi munkavállalás - kivándorlás (I21, I31)

Az itthoni munkaerőpiacon relatíve stabil helyzetben lévők, akik a válság előtt szerényen megéltek és tudták fizetni a törlesztőrészletet, a részlet folyamatos emelkedésével olyan helyzetbe kerülhettek, melyből kiutat csak a külföldi munkavállalás jelentett. Ez lehetővé tette az itthoni lakás megtartását azzal, hogy megteremtette a törlesztőrészletre szükséges forrást. Vagyis a munka szempontjából instabil helyzetben lévők vagy alacsony jövedelemmel rendelkezők esetében a stabilitás megteremtését csak külföldi munkavállalással lehet elérni. Ez látszik az egyetlen olyan alternatívának, melyen keresztül a helyzet valamenynyire konszolidálható, esetleg hosszabb távon akár még javítható is lehet.

6. Eszközkezelő - államibérlakás-konstrukció (I32, I39)

A Nemzeti Eszközkezelő által biztosított megoldás lehetőséget adott arra, hogy a családok megtarthassák a lakásukat, és 5 évig biztosította azt a jogot, hogy visszavásárolhassák. Nagyon kis arányban éltek ezzel a családok, bár a 2015 utáni lakásár-növekedés miatt a visszavásárlás gazdasági előnyei egyértelmúek. A NET által kezelt ócsai lakásokba már csak olyan családok kerültek, akik elveszítették lakásukat, albérletbe kényszerültek. A NET-lakások esetében a bérlők 10-15\%-a vált hátralékossá, mert a piacinál lényegesen alacsonyabb lakbért nem tudta, nem akarta fizetni. Ezek a családok egy, a Máltai Szeretetszolgálat és a Református Egyház szociális szervezetei által bonyolított programba kerültek. Ide sok olyan család került, akik számára a lakásvásárlás eleve reménytelen vállalkozás volt, de egy stabil, megfizethető bérlakás-pozíció már komoly előrelépés a hitelfelvétel előtti bizonytalan lakáshelyzetekhez képest.

A most felvázolt alternatívák a lakásrezsimen belül a bizonytalan pozíciók újbóli megerősödését jelentik, azokat a helyzeteket, amelyekben a lakhatás feltételei távol esnek a társadalmilag (a családok és a politika által) preferált megoldásoktól, egyfajta marginális helyzetet, amelyből a családok a lakáshitelek segítségével kívántak kitörni. 


\section{Következtetések}

A rendszerváltást követő évtizedben a Magyarországon kiépült, kvázi piaci elemeket is felhasználó szocialista lakásrendszert egy ellentmondásos, piaci alapú lakásrezsim váltotta fel. Ebben a tulajdonos által lakott magántulajdonlás vált a meghatározó elemmé, amitől mind a szociális-önkormányzati, mind a magánbérleti szektor egyre távolabb kerül, a lakásminőség és a háztartások társadalmi összetétele tekintetében egyaránt.

A 2000-es évek elején megfogalmazódott lakáspolitika ezt a lakásrezsimet két ponton kívánta változtatni: a bérleti szektor erősítésével (mind a szociális, mind a piaci szférán belül), illetve a lakásfinanszírozási rendszer korszerúsítésével kívánta a piaci lakásépítést/vásárlást a társadalom tagjai számára megfizethetővé tenni. Míg a bérlakás-szektor erősítését célzó programok kudarcot vallottak (a megfelelő politikai és gazdasági érdekek hiányában), addig a hitelexpanzióra épülő lakáspolitika élvezte a politikai és gazdasági lobbik támogatását, veszélyeztetve a makrogazdasági egyensúlyt: 2000 és 2004 között gyakorlatilag finanszírozhatatlan hiteltámogatással, 2004 és 2008 között pedig az alacsony kamatozású, kockázatos devizahitelek révén.

A hitelpiac kiszélesítése, és különösen a devizaalapú hitelezés széles körű elterjedése a meglévő lakásrezsim domináns modellje, tehát a piaci integrációjú, magántulajdonú lakásforma megszilárdítását célozta. Ezt a folyamatot az egységes értelmezés is segítette, amelyben a jelzálog-hitelezésre épülő megoldás sikeresnek tűnt mind az intézményi szereplők számára (állam, bankok, Nemzeti Bank, fejlesztők stb.), mind a lakossági oldalon.

A 2008-as válság alapvetően megváltoztatja a helyzetet. A devizahitelek veszteségessé válnak, és ennek költségeit a szereplőknek viselniük kell. Megindul a felelős keresése, minden szereplő a veszteség költségeinek egy másik félre történő hárításában érdekelt. A többé-kevésbé egységes felfogást a szereplők alternatív magyarázatai/értelmezései és az ezekhez kapcsolt megoldási javaslatok váltják fel. A devizaválság („veszteségek”) kezelésére különböző állami programok indulnak, de a szereplők alkalmazkodási stratégiái és viselkedése újra megerôsítik a lakásrezsim torz elemeit. A 2018 végén bejelentett kedvezményes visszavásárlási (privatizációs) lehetőség a Nemzeti Eszközkezelő által felállított szociális állami szektor felszámolási tervével egyenlő, az állam szociális lakáspolitikai szerepének visszalépésével. 2016 után tehát a gazdaság (EU-támogatásokból finanszírozott) stabilizációjára épülő lakáspolitika ismét a piaci finanszírozású magántulajdonra épít, elfeledkezve a megelőző másfél évtized kudarcáról.

\footnotetext{
Abstract: The paper analyses the expansion and crisis of the FX (foreign currency) loan market and the mortgage rescue programs introduced in response, in the context of the Hungarian housing regime. The housing market expanded through mortgage lending from around 2000, initially thanks to substantial interest rate subsidies by the state. After 2004, low-interest, high-risk FX loans replaced subsidised loan products, allowing continued market expansion. Housing policies that pushed for privatisation and replaced the state-financed housing solutions by the private banks' mortgage products led to a distorted housing regime that incentivises private ownership for lower income social strata as well. Initially, as the
} 
economy grew and living standards increased for many, this seamed feasible both to institutional actors and the broader society, resulting in a shared narrative concerning preferences and responsibilities. The 2008 crisis substantially changed this, as FX loans became unaffordable. Various actors had conflicting interests in placing blame and paying for losses. This led to the fragmentation of the shared narrative, and consequently, incompatible proposed solutions. We argue that the coping strategies and broader behaviour of the participants reinforced the disproportionate elements of the housing regime. After 2015, housing policies again rely on economic stabilisation, this time subsidised by the EU, incentivising market solutions for private home ownership and disregarding the experiences of the past decades.

Keywords: housing regime, housing strategy, FX borrowing, coping strategies of households

\section{Irodalom}

Aalbers, M. B. (2008): The financialization of home and the mortgage market crisis. In Aalbers, M. B. (ed.): The Financialization of Housing. London: Routledge, 40-63. Augustyniak, H., Csizmady, A., Hegedüs, J., Łaszek, J., Olszewski, K., Somogyi, E. (2019): Post-socialist housing systems: Convergence or divergence? A comparative analysis of FX-lending in Poland and Hungary (kézirat).

Ball, M., Harloe, M. (1992): Rhetorical barriers to understanding housing provision: What the 'provision thesis' is and is not. Housing Studies, 7 (1): 3-15. DOI: https:// doi.org/10.1080/02673039208720719.

Barrell, R., Davis, E. F., Fic, F., Orazgani, A. (2009): Household Debt and Foreign Currency Borrowing in New Member States of the EU. Working Paper No. 09-23. Brunel University West London, Department of Economics and Finance.

Beck, U. (1992): Risk Society: Towards a New Modernity. New Delhi: Sage.

Berglof, E. (2015): New structural economics meets european transition. Journal of Economic Policy Reform, 18(2): 114-130. DOI: https://doi.org/10.1080/1748787 0.2015.1013543.

Bethlendi, A. (2009): A hazai hitelpiac empirikus vizsgálata fejlődési irányok, makrogazdasági és pénzügyi stabilitási következmények. PhD-értekezés, Budapesti Müszaki Egyetem.

Bethlendi, A. (2015): Egy rossz termékfejlesztésből rendszerszintú piaci kudarc. A hazai lakossági deviza jelzáloghitelezés. Hitelintézeti Szemle, 14 (1): 5-29.

Bohle, D. (2014): Post-socialist housing meets transnational finance: Foreign banks, mortgage lending, and the privatization of welfare in Hungary and Estonia. Review of International Political Economy, 21 (4): 913-48. DOI: https://doi.org/10.1080/0 9692290.2013.801022.

Csillag, I., Mihályi, P. (2011): Tizenkét érv a devizahitelesek megmentése ellen. Népszabadság, május 14.

Csizmady, A., Hegedüs, J. (2016): „Hungarian Mortgage Rescue Programs 20092016”. NBP Working Paper No. 243 The Narodowy Bank Polski Workshop: Recent trends in the real estate market and its analysis. Vol. 1. Economic Institute Warsaw, 11-34. 
Dancsik, B., Fábián, G., Fellner, Z., Horváth, G., Lang, P., Nagy, G., Oláh, Zs. - Winkler, S. (2015): A nemteljesítő lakossági jelzáloghitel-portfólió átfogó elemzése. MNBtanulmányok különszám.

Doling, J., Ronald, R. (2010): Home ownership and asset-based welfare. Journal of Housing and the Built Environment, 25 (2): 165-173. DOI: https://doi.org/10.1007/ s10901-009-9177-6.

Erbenova, M., Liu, Y., Saxegaard, M. (2011): Corporate and Household Debt Distress in Latvia: Strengthening the Incentives for a Market-Based Approach to Debt Resolution. IMF Working Paper 11/85.

Ferrera, M. (1996): The 'southern model' of welfare in social Europe. Journal of European Social Policy, 6 (1): 17-37. DOI: https://doi.org/10.1177/095892879600600102.

Fitzpatrick, S., Stephens, M. (2014): Welfare regimes, social values and homelessness: Comparing responses to marginalised groups in six European countries. Housing Studies, 29 (2): 215-34. DOI: https://doi.org/10.1080/02673037.2014.848265.

Gáspár, K., Varga Zs. (2011): A bajban lévő lakáshitelesek elemzése mikroszimulációs modellezéssel. Közgazdasági Szemle, 58 (6): 529-542.

Giddens, A. (1999): Runaway World: How Globalization is Reshaping Our Lives. London: Profile Books.

GKI (2015): Magyarország külső adósságállományának és a külföldiek kezében lévő adósságának elemzése. Budapest: Gazdaságkutató Intézet.

GM (2000): Széchenyi Terv. Lakásprogram. Gazdasági Minisztérium, Budapest.

Haffner, M., Hoekstra, J., Oxley, M., van der Heijden, H. (eds.) (2009): Bridging the Gap between Social and Market Rented Housing in Six European Countries? Amszterdam: IOS Press.

Hegedüs J. (2006): Lakáspolitika és a lakáspiac - a közpolitika korlátai. Esély, 18 (5): 65-100.

Hegedüs, J. (2018): Lakásrezsimek rendszerváltás előtt és után a posztszocialista államokban. In Bozóki A., Füzér K. (szerk.): Lépték és irónia : Szociológiai kalandozások. Budapest: MTA Társadalomtudományi Kutatóközpont, 73-125.

Hegedüs, J., Struyk, R. (2005): Divergences and convergences in restructuring housing finance in transition countries. In Hegedüs, J., Struyk, R. J. (eds.): Housing Finance: New and Old Models in Central Europe, Russia and Kazakhstan. LGI Books, Open Society Institute, 3-41.

Hojsik, M. (2013) Slovakia: On the Way to the stable social houisng concept. In Hegedüs, J., Lux, M., Teller, N. (eds.): Social Housing in Transitional Countries. London: Routledge, 262-277.

Kemeny, J. (1995): From Public Housing to the Social Market: Rental Policy Strategies in Comparative Perspective. London: Routledge.

Kemeny, J., Kersloot, J., Thalman, P. (2005): Non-profit housing, influencing, leading and dominating the unitary rental market: three case studies. Housing Studies, 6., 855-872. DOI: https://doi.org/10.1080/02673030500290985. 
Király, J. (2019): A tornádó oldalszele. Személyes válságtörténelem. Budapest: Park Könyvkiadó 2019 (megjelenés alatt).

Király, J., Nagy M. (2008): Jelzálogpiacok válságban: kockázatalapú verseny és tanulságok. Hitelintézeti Szemle, 7 (5): 450-482.

KSH (2011) A hitellel rendelkező háztartások szociális jellemzői.

Lentner, Cs. (szerk.) (2015): A devizahitelezés nagy kézikönyve. Budapest: Nemzeti Közszolgálati és Tankönyv Kiadó.

Lin, J. Y. (2012): New Structural Economics: A Framework for Rethinking Development and Industrial Policy. Washington, DC: World Bank.

Lundqvist, L. J. (1990): Rolling Stones for the Resurrection of Policy as the Focus of Comparative Housing Research. Paper presented at the International Housing Conference Housing Debates - Urban Challenges', Paris, 3-6 July.

Malpass, P. (2008): Housing and the new welfare state: Wobbly pillar or cornerstone? Housing Studies, 23 (1):1-19. DOI: https://doi.org/10.1080/02673030701731100.

Matznetter, W. (2002): Social housing policy in a conservative welfare state: Austria as an example. Urban Studies, 39 (2): 265-82. DOI: https://doi. org/10.1080/00420980120102966.

Matznetter, W., Mundt, A. (2012): Housing and welfare regimes. In Calpham, D. F., Clark, W. A. V., Gibb, K. (eds.): The SAGE Handbook of Housing Studies. London: Sage Publications, 274-94.

Medgyesi, M. (2008): Jut is? Marad is? A háztartások megtakarításai. In Szivós P. - Tóth I. Gy. (szerk.): Köz, teher, elosztás Budapest: Tárki Monitor Jelentések, 155-173.

MNB (2009): Jelentés a pénzügyi stabilitásról, 2009. november.

MNB (2010) Jelentés a pénzügyi stabilitásról, 2010. április.

Növekedéskutató Intézet (1999): Reális lakáspolitika.

Oblath, G. (2010): Ki, miben felelős? Észrevételek Surányi György diagnózis- és terápia-kritikájához. KTI-blog.

OGY (2012): Az Országgyúlés Alkotmányügyi, igazságügyi és ügyrendi bizottságának jelentése a 2002-2010 közötti lakossági devizaeladósodás okainak feltárásáról, valamint az esetleges kormányzati felelősség vizsgálatáról.

Otthon Európában (2003): Otthon Európában - A nemzeti lakásprogram pillérei. Budapest: Nemzeti Lakásprogram Iroda.

Pásztor, S. (2011): Kódolt kifulladás. Válság a gépjárműpiacon. Közgazdasági Szemle, 58 (2): 173-189.

Pavlovskaya, M. (2004): Other transitions: Multiple economies of Moscow households in the 1990s. Annals of the Association of American Geographers, 94 (2): 329-351. DOI: https://doi.org/10.1111/j.1467-8306.2004.09402011.x.

Pellandini-Simányi, L., Hammer, F., Vargha, Zs. (2015): The financialization of everyday life or the domestication of finance? How mortgages shape borrowers' temporal horizons, relationships and rationality in Hungary. Cultural Studies, 29 (5-6): 733-759. DOI: https://doi.org/10.1080/09502386.2015.1017142. 
Pete, P. (2010) Felelős. Magyar Narancs, 2010/7, http://magyarnarancs.hu/egotripp/ felelos-73196.

Pósfai, Zs., Gál, Z., Nagy, E. (2018): Financialization and inequalities (The uneven development of the housing market on the Eastern periphery of Europe). In , S. Tridico, P. (eds.): Inequality and Uneven Development in the Post-Crisis World. London: Routledge, 167-190.

PSZÁF (2012): Gyorselemzés a végtörlesztésről. Pénzügyi Szervezetek Állami Felügyelete, https://www.mnb.hu/letoltes/gyorselemzes-vegtorlesztes-120312j.pdf. Ries, N. (1997): Russian Talk: Culture and Conversation during Perestroika. Ithaca, NY: Cornell University Press.

Róna, P. (2013): Hibás termék. Magyar Nemzet, 2013. augusztus 8. http://balazs.pergamen.hu/downloads/hibas_termek.pdf.

Surányi, Gy. (2010): Téves diagnózis, téves terápia. Népszabadság, 2010. január 30. http://nol.hu/gazdasag/teves_diagnozis_teves_terapia-525601.

Surányi, Gy. (2015): A jegybank mindenben hibázott, amiben lehetett. Origo, 2015. 2. 24. http://www.origo.hu/gazdasag/20150223-suranyi-gyorgy-a-jegybankmindenben-hibazott-amiben-lehetett.html.

Szabó, N. (2018): We are the State, we are the people: Forex loan debtors' struggles for citizenship in Hungary. MA thesis, Budapest: Central European University Department of Sociology and Social Anthropology.

Szokoli, E. (2014): Konfliktusok és társadalmi mozgalmak a jól-lét kontextusában: a kamattartozást felhalmozók mozgalma. In Hervainé dr. Szabó Gy., Folmeg M. (szerk.): Társadalmi válságok, konfliktusok a jól-lét kontextusában. Kodolányi János Főiskola, 155-181.

Tóth, I. J., Árvai, Zs. (2001): Likviditási korlát és fogyasztói türelmetlenség. A magyar háztartások fogyasztási és megtakarítási döntéseinek empirikus vizsgálata. Közgazdasági Szemle, 48 (12): 1009-38.

Várhegyi, É. (2018): Bankcsapda. Magyar Narancs, 2018/8, http://magyarnarancs. hu/publicisztika/bankcsapda-109480.

Várhegyi, É. (2010): Hitelek fogságában. Élet és Irodalom, 39. 


\section{3. táblázat: Strukturált interjúk összefoglaló táblázata}

\begin{tabular}{|c|c|c|c|c|c|c|}
\hline $\begin{array}{l}\text { Interjú- } \\
\text { azonosító }\end{array}$ & Melyik típus? & Család & Magánbérlet & $\begin{array}{c}\text { Rossz } \\
\text { lakáshelyzet }\end{array}$ & $\begin{array}{c}\text { Állami } \\
\text { támogatás }\end{array}$ & Devizahitel \\
\hline interju_1 & 7 & $\begin{array}{l}\text { hp+5 } \\
\text { gyermek }\end{array}$ & igen & igen & igen & nem \\
\hline interju_2 & 7 & $\begin{array}{l}\mathrm{hp}+3 \\
\text { gyermek }\end{array}$ & igen & igen & igen & nem \\
\hline interju_3 & 7 & $\begin{array}{l}\mathrm{hp}+3 \\
\text { gyermek }\end{array}$ & igen & igen & igen & igen \\
\hline interju_4 & 2,3 & $\begin{array}{l}\mathrm{hp}+4 \\
\text { gyermek }\end{array}$ & nem & igen & nem & igen \\
\hline interju_5 & 2 & $\begin{array}{l}\mathrm{hp}+4 \\
\text { gyermek }\end{array}$ & igen & igen & igen & igen \\
\hline interju_6 & 7 & $\begin{array}{l}\text { hp+3 } \\
\text { gyermek }\end{array}$ & nem & nem & igen & igen \\
\hline interju_7 & 4 & $\begin{array}{l}\text { hp+3 } \\
\text { gyermek }\end{array}$ & igen & igen & nem & igen \\
\hline interju_8 & 4 & nyugdíjas pár & nem & igen & nem & igen \\
\hline interju_9 & 4 & $\begin{array}{l}\text { hp+2 } \\
\text { gyermek }\end{array}$ & igen & nem & nem & igen \\
\hline interju_10 & 4 & $\begin{array}{l}\text { hp } \\
\text { (egyedülálló) }\end{array}$ & nem & igen & nem & igen \\
\hline interju_11 & 7 & egyedülálló & nem & igen & nem & igen \\
\hline interju_12 & 4 & $\begin{array}{l}\text { házas }+ \\
\text { unoka }\end{array}$ & nem & igen & nem & igen \\
\hline interju_13 & 7 & egyedülálló & nem & igen & nem & igen \\
\hline interju_14 & 2 & egyedülálló & nem & igen & igen & nem (is) \\
\hline interju_15 & 2 & egyedülálló & igen & nem & nem & igen \\
\hline interju_16 & 2,3 & $\mathrm{hp}+2$ gyerek & nem & nem & nem & igen \\
\hline interju_17 & 4 & hp+1 gy. & nem & igen & nem & igen \\
\hline interju_18 & 1 & hp+gyerek & igen & igen & nem & igen \\
\hline interju_19 & 2 & hp+gyerek & nem & igen & nem & igen \\
\hline interju_20 & 7 & hp+gyerek & igen & igen & nem & igen \\
\hline interju_21 & 5 & egyedülálló & igen & igen & nem & igen \\
\hline interju_22 & 4 & $\mathrm{hp}$ & nem & Igen & nem & igen \\
\hline interju_23 & 7 & egyedülálló & nem & nem & igen & nem \\
\hline interju_24 & 7 & $\mathrm{hp}$ & igen & nem & nem & igen \\
\hline interju_25 & 7 & hp+2 gyerek & igen & igen & nem & igen \\
\hline interju_26 & 2 & $\mathrm{hp}$ & igen & igen & nem & igen \\
\hline interju_27 & 7 & \begin{tabular}{|l} 
elvált+1 \\
gyerek
\end{tabular} & nem & igen & igen & nem \\
\hline interju_28 & 4 & hp+3 gyerek & nem & igen & igen & igen \\
\hline interju_29 & 4 & \begin{tabular}{|l|} 
elvált +2 \\
gyerek
\end{tabular} & nem & nem & nem & igen \\
\hline interju_30 & 8 & $\begin{array}{l}\text { elvált + } \\
\text { egyedül él }\end{array}$ & nem & nem & nem & igen \\
\hline interju_31 & 5 & $\begin{array}{l}\text { hp + négy } \\
\text { gyerek }\end{array}$ & igen & n.a. & n.a. & igen \\
\hline Interju_32 & 6 & hp+8 gyerek & nem & igen & igen & \\
\hline Interju_33 & 2 & $\begin{array}{l}\text { elvált + } 3 \\
\text { gyerek }\end{array}$ & nem & nem & nem & igen \\
\hline Intetju_34 & 6 & $\begin{array}{l}\text { elvált + } 1 \\
\text { gyerek }\end{array}$ & nem & nem & nem & igen \\
\hline Interju_35 & 8 & $\mathrm{hp}+1$ gyerek & nem & nem & nem & igen \\
\hline Interju_36 & 3 & hp+3 gyerek & nem & nem & nem & igen \\
\hline Interju_37 & 7 & hp+1 gyerek & nem & nem & nem & igen \\
\hline interju_38 & 2 & hp+2 gyerek & igen & nem & nem & igen \\
\hline interju_39 & 6 & $\mathrm{hp}$ & nem & nem & igen & igen \\
\hline
\end{tabular}


Típusok:

1. Visszaköltözés a szülőkhöz és a lakás kiadása

2. Lemondás a lakásról, albérletbe költözés

3. Lemondás a lakásról, szülőkhöz, rokonokhoz visszaköltözés

4. Minden erőforrás mozgósítása jelentős anyagi áldozat árán, a lakás megtartásával

5. Külföldi munkavállalás

6. Eszközkezelő - államibérlakás-konstrukció

7. Nem került bajba, vagy a családja révén másik lakáshoz jutott /másikat tudott vásárolni

8. Végrehajtás alatt - még nem lehetett tudni, milyen utat fog bejárni 